\title{
ANTIBACTERIAL ACTIVITIES OF SAPODILLA FRUIT EXTRACT INHIBITING SALMONELLA TYPHI ON MICE BALB/C
}

\author{
HASTA HANDAYANI IDRUS ${ }^{1,2 *}$, MOCHMAMMAD HATTA ${ }^{3}$, AMI FEBRIZA ${ }^{4}$, VIVIEN NOVARINA A. KASIM ${ }^{5}$ \\ ${ }^{1}$ Departement of Microbiology, Faculty of Medicine, University Muslim Indonesia, Makassar, Indonesia. ${ }^{2}$ Department of Molecular Biology \\ and Immunology, Faculty of Medicine, Universitas Hasanuddin, Makassar, Indonesia. ${ }^{3}$ Department of Immunology and Microbiology, \\ Faculty of Medicine, Universitas Hasanuddin, Makassar, Indonesia. ${ }^{4}$ Department of Nursing, Faculty of Sport and Health, State University \\ of Gorontalo, Gorontalo, Indonesia. ${ }^{5}$ Department of Physiology, Faculty of Medicine, University of Muhammadiyah Makassar, Makassar, \\ Indonesia. Email: hastahandayani@umi.ac.id \\ Received: 17 April 2019, Revised and Accepted: 19 July 2019
}

ABSTRACT

Objective: The aim of this study was to see the effectiveness of brown manila extract in inhibiting the growth of Salmonella typhi Thy1 bacteria in peritoneal fluid male mice strain BALB/c.

Methods: We use manila extract which has been obtained from the extraction of the maceration method and uses the plate count agar (PCA) method to calculate the number of colonies after conducting bacterial culture before and after the intervention.

Results: The results obtained were a significant decrease of bacterial colonies after administration of manila extract $510 \mathrm{mg} / \mathrm{kgBW}$ value $\mathrm{p}=0.009 \mathrm{and}$ extract of brown manila $750 \mathrm{mg} / \mathrm{kgBB}$ value $\mathrm{p}=0.007$.

Conclusion: Giving extract of mano manila $510 \mathrm{mg} / \mathrm{kgBB}$ and $750 \mathrm{mg} / \mathrm{kgBB}$ has effectiveness in suppressing the growth of $S$. typhi Thy1.

Keywords: In vivo study, Sapodilla fruit extract, Salmonella typhi Thy1.

(c) 2019 The Authors. Published by Innovare Academic Sciences Pvt Ltd. This is an open access article under the CC BY license (http://creativecommons. org/licenses/by/4. 0/) DOI: http://dx.doi.org/10.22159/ijap.2019.v11s5.T0095

\section{INTRODUCTION}

Typhoid fever is a disease caused by Salmonella typhi bacteria that can be controlled through clinical information that is used by the patient, a diagnosis enforced by health workers, and public understanding of the epidemiology of this disease. There are still many things that are a mystery about how $S$. typhi bacteria can adapt to humans and cause quite complex problems in society. Many things can become obstacles in controlling this disease, one of which is the high resistance of antibiotics that many sufferers experience [1]. Typhoid disease can be transmitted through food and beverages contaminated by S. typhi bacteria which are mostly carried by vectors of legs of flies, cockroach legs, and mouse feet. Some studies suggest that typhoid fever can also be transmitted by asymptomatic sexual intercourse [2]. Some areas that are in the endemic areas of typhoid fever are Latin America, Africa, and Asia, and humans are the only reservoir of $S$. typhi bacteria, which is currently known [3].

S. typhi bacteria are a group of Gram-negative bacteria that have resulted in many cases of death in the world each year [4]. This bacterium is an intracellular pathogen that can live in a host cell or human body by forming itself into a vacuole and living in the cytoplasm [5]. One type of $S$. typhi which causes many food pathogens worldwide is S. typhi Thy1 [6]. Thy1 S. typhi is pathogenic in humans and animals and is found in contaminated food and beverages. S. typhi Thy1 is often found in cases of gastroenteritis and typhoid fever because it can cause pathogenicity to the human body [7].

Global data found in the incidence of typhoid fever every year reaches 12-22 million cases, and in many cases, it is found in people who are middle to lower income [8]. The first choice of treatment for this disease still uses fluoroquinolone antibiotics such as levofloxacin, ciprofloxacin, and ofloxacin. However, the high incidence of antibiotic resistance, especially in the South Asian region, has led researchers to consider looking for new strategies to control typhoid fever [9]. This is the background of the researchers to examine herbal plants that can be a replacement therapy for typhoid fever cases; one of the plants that have been widely used empirically in Indonesia is Sawo Manila (Achras zapotaL).

Manila sapodilla fruit was first discovered in America in tropical climates, and the fruit has been consumed by many people there as a dessert, the basic ingredient in making a pie and canned fruit [10]. Manila sapodilla trees are also commonly found in Southern Mexico and are not only consumed by local people [11] but are also exported in the form of processed fruit because ripe fruit tastes sweet and is very popular with people [12]. Based on preliminary research conducted by the researcher, namely, extracting the maceration method and conducting phytochemical tests the quality of the content of raw manila sapodilla fruit was found to contain flavonoids, tannins, and terpenoids which are the main antibacterial components contained in raw brown manila fruit. One of the bacteria that can be suppressed by raw manila sapodilla fruit is a bacterium that causes typhoid fever, namely, S. typhi.

\section{METHODS}

This study is a true experimental pre- and post-test design using the plate count agar (PCA) method by calculating the number of colonies in agar after conducting bacterial culture, the aim is to see the effectiveness of manila extract in inhibiting the growth of $S$. typhi Thy1 bacteria in peritoneal fluid male mice strain BALB/c.

\section{Maceration extraction}

Sapodilla fruit which amounts to 100 pieces weighing $15 \mathrm{~kg}$ and has been cut into small pieces then the researchers take it to the Hasanuddin University Pharmacy Laboratory for extraction and phytochemical testing.

Making extracts of maceration method have four steps: Drying process where the sample to be made into an extract is first to cut into small 
parts and then dried at $50^{\circ} \mathrm{C}$ with the aim of minimizing the water content in the sample using OVL-1 electric dryer [13].

Manila sapodilla fruit which has been homogenized then washed the fruit skin cleanly using clean tap water and then drained and prepared for cutting. Cutting is done using a sharp and clean knife without peeling the skin first in other words; we cut the fruit with the skin. Cutting is done by cutting the two fruits together and then releasing the seeds and then cutting the fruit into eight small parts [14].

Maceration process where the dried sample is then put into a glass container/jar for maceration process by adding ethanol CAS number 64-17-5 with EC number index 603-002-00-5 EC number 200-578-6 ACS grade, ISO, Reag. Ph Eur is $96 \%$, then left to $3 \times 24 \mathrm{~h}$ [15].

They are followed by the filtration process where samples which have been macerated for $3 \times 24 \mathrm{~h}$ are then filtered using vacuum filtration method using L127C/175 ml Buchner Funnel 1PC. Next is the evaporation process where the extract solution obtained after the screening process is then evaporated using a rotary-evaporator $2 \mathrm{~L}$ R-1001 VN device to obtain a thick extract [16].

Extraction results with maceration methods obtained from raw manila sapodilla fruit amounting to 100 pieces weighing $15 \mathrm{~kg}$ were $150 \mathrm{ml}$ of dark brown thick extract liquid with a distinctive odor like sweet gum odor. This means that the average weight of 1 raw manila sapodilla is $150 \mathrm{mg}$ and has the potential to produce $1.5 \mathrm{ml}$ of thick extract liquid.

\section{Preparation and adaptation of try animals}

This stage is the preparation and adaptation stage of experimental animals that will be used during the research. The experimental animals used were male strain BAB/c mice aged 12-14 weeks. The first mice are placed in a plastic cage above which is covered with an iron net with a cage area of $30 \mathrm{~cm} \times 50 \mathrm{~cm} \times 15 \mathrm{~cm}$. Mice placed in each cage contained six tails. Ratio brand standard feed is given to mice as much as $300 \mathrm{~g} / \mathrm{h} /$ head and given enough drink, and the cage is cleaned every day. To maintain a stable environment, mice are placed in a room with sufficient air circulation and are maintained in accordance with the room temperature at standard conditions $\left(28 \pm 2^{\circ} \mathrm{C}\right)$ with $50 \pm 10 \%$ humidity and a $12 \mathrm{~h}$ cycle room light and $12 \mathrm{~h}$ extinguished. This procedure is carried out for 1 week. Next, mice were randomized.

Allmicewere thengroupedinto fourgroupsrandomly,namely,thenegative control group, Group I (sapodilla manila fruit extract $510 \mathrm{mg} / \mathrm{BB} / \mathrm{day}$ ), Group II (sapodilla manila fruit extract $750 \mathrm{mg} / \mathrm{BB} /$ day), positive control group (levofloxacin antibiotics $98 \mathrm{mg} / \mathrm{BB} /$ day), and negative control group (aquades $10 \mathrm{mg} / \mathrm{BB} /$ day). The intervention was carried out for 5 days. After the $5^{\text {th }}$ day, mice are then maintained for 3 weeks to find out the number of colonies in the post-intervention period, or we have a chronic phase.

\section{S. typhi induction}

This stage is the stage where all mice numbering 24 and have been divided into four groups, namely, Group I (sapodilla manila fruit extract $510 \mathrm{mg} / \mathrm{BB} /$ day), Group II (sapodilla manila fruit extract $750 \mathrm{mg} / \mathrm{BB} /$ day), control group positive (levofloxacin antibiotic $98 \mathrm{mg} / \mathrm{BB} /$ day), and negative control group $(10 \mathrm{mg} / \mathrm{BB} /$ day aquades) each induced with $3 \mathrm{ml} \times 103 \mathrm{ml} / \mathrm{CFU}$ S. typhi Thy1 bacteria intraperitoneally using 0.5 dispo cc B-Braun.

\section{Giving manila sapodilla extract}

We used brown manila extract, which was obtained from the extraction of maceration method in the form of thick sapodilla fruit extract, which was then diluted using a dilution method by adding BR-2 distilled water. Manila extract was given orally in two different doses for different groups and emulsified with BR-2 distilled water. Therapy of manila extract will begin 3 days after infection with $S$. typhi Thy1. We used the following doses $510 \mathrm{mg} / \mathrm{kg}$ of mice body weight per day and $750 \mathrm{mg} / \mathrm{kg}$ of mice body weight per day. Emulsified manila sapodilla extract was administered orally using a nasogastric tube sonde silicone Frekat Tube brand Fr 12 silicon size 12 for 5 days.

We provide manila extract with doses that have been converted by estimating animal doses using human-animal conversion factors (0.0026). Where the prescribed dose is $510 \mathrm{mg}$ extract of brown manila/10 g BB mice/0.1 cc aquades (Group I) and $750 \mathrm{mg}$ extract of sapodilla manila/10 g BB mice/0.1 cc aquades (Group II) given orally use the Frekat Tube brand nasogastric tube sonde silicone belly tube Fr 12 size 12 silicone every $24 \mathrm{~h}$ for 5 days.

\section{Levofloxacin administration (positive control) and aquades (negative} control)

Based on research conducted, levofloxacin was found to be the most effective uncomplicated typhoid drug. We estimate animal doses using human-animal conversion factors (0.0026). We used the same dose for the positive control group ( $1.95 \mathrm{mg} /$ day), which is $98 \mathrm{mg}$ levofloxacin $/ 10 \mathrm{~g} \mathrm{BB}$ mice $/ 0.1 \mathrm{cc}$ aquades and distilled water $0.1 \mathrm{cc} / 10$ g BB mice (negative control). Levofloxacin is administered orally using a nasogastric Frekat Tube sonde silicone abdominal tube Fr 12 silicon size 12 every $24 \mathrm{~h}$ for a week.

\section{Peritoneal liquid sampling}

The technique of taking peritoneal fluid in mice was carried out by mice fixed in the supine position, and then the abdomen was cleaned with $70 \%$ alcohol and injected with $0.8-1 \mathrm{ml} \mathrm{NaCl}$ into the peritoneal cavity. Then, let stand for $1 \mathrm{~min}$ while rocking slowly. Peritoneal fluid is removed from the peritoneal cavity with the position of mating on the back; then, the liquid is aspirated with dispo $0.5 \mathrm{cc}$ B-Braun as much as $0.5 \mathrm{ml}$. The taking of peritoneal fluid was carried out 3 times, namely, on the $4^{\text {th }}$ day after the mice were induced by $S$. typhi Thy 1 bacteria, the last day was 5 days of intervention and 3 weeks after administration of the manila extract.

\section{Culture and calculation of the number of colonies}

The PCA method is a technique for growing microorganisms in the agar medium by mixing a liquid agar medium with a bacterial culture stock so that the cells are spread evenly and quietly on the agar surface or inside so (Brugger et al., 2012). This method was carried out by diluting $0.5 \mathrm{ml}$ peritoneal fluid sample into $4.5 \mathrm{ml}$ of physiological salt $(0.9 \% \mathrm{NaCl})$ brand Emsure ACS, ISO, Reag. Ph Eur. Dilution is done 3 times by mixing 0.5 cc samples of $S$. typhi Thy 1 bacteria with $4.5 \mathrm{ml}$ of $0.9 \% \mathrm{NaCl}$ so that the culture obtained is not too dense or meets the cup because cultures that are too dense will interfere with the process of observing the test bacteria. Approximately $1 \mathrm{ml}$ of suspension was poured into the Iwaki sterile Petri dish culture dish treated $59 \times 15 \mathrm{~mm}$, followed by pouring sterile Agarose $100 \mathrm{BR}$ warm nutrient media $\left(45^{\circ} \mathrm{C}\right)$ then tightly closed and incubated for $2 \times 24 \mathrm{~h}$ at $37^{\circ} \mathrm{C}$. After that, we calculated the number of $S$. typhi Thy1 bacteria found. The calculation of $S$. typhi Thy1 bacteria grown on the medium was done 3 times, namely, samples originating from bacterial-induced mice on the $4^{\text {th }}$ day, samples taken after 5 days of intervention and samples taken 3 weeks after administration of the manila extract.

\section{RESULTS AND DISCUSSION}

In Table 1 shows the distribution of data from the calculation of Salmonella bacteria from Thy 1 before the therapeutic intervention, after the $5^{\text {th }}$ and $30^{\text {th }}$ day of days manila extract therapy intervention after the intervention of manila extract. The bacterial colonies were then calculated from the sampling of peritoneal fluid from mice.

Fig. 1 shows the results of the calculation of Salmonella bacteria Thy 1 3 days after Salmonella bacteria induced in Thy1, we can see the number of colonies of Salmonella bacteria from Thy1 in four groups with different numbers from the four groups.

Table 2 shows that the results of the calculation of the average Salmonella bacterial colonies on Thy1 in the four groups of manila 
Table 1: Distribution of data on the calculation of Salmonella bacteria from Thy1 before the intervention and after the intervention

\begin{tabular}{|c|c|c|c|c|}
\hline Sample & $\begin{array}{l}\text { Log of colony } \\
\text { count sapodilla } \\
510 \mathrm{mg} / \mathrm{kg} \mathrm{BB}\end{array}$ & $\begin{array}{l}\text { Log of colony } \\
\text { count sapodilla } \\
750 \mathrm{mg} / \mathrm{kg} \mathrm{BB}\end{array}$ & $\begin{array}{l}\text { Log of colony count } \\
\text { levofloxacin } 98 \mathrm{mg} / \mathrm{kg} \\
\text { BB (positive control) }\end{array}$ & $\begin{array}{l}\text { Log of colony count } \\
\text { aquades } \\
\text { (negative control) }\end{array}$ \\
\hline Colony count before & 20 & 17 & 31 & 22 \\
\hline \multirow{5}{*}{ therapy $\left(10^{3} \mathrm{CFU}\right)$} & 22 & 15 & 34 & 32 \\
\hline & 26 & 17 & 39 & 19 \\
\hline & 25 & 21 & 29 & 16 \\
\hline & 30 & 16 & 19 & 24 \\
\hline & 24.6 & 17.2 & 30.4 & 22.6 \\
\hline Colony count before & 1 & 0 & 0 & 12 \\
\hline therapy (day 5) $10^{3}$ & 0 & 0 & 0 & 15 \\
\hline \multirow[t]{4}{*}{$\mathrm{CFU}$} & 0 & 0 & 0 & 10 \\
\hline & 0 & 0 & 0 & 12 \\
\hline & 0 & 0 & 4 & 20 \\
\hline & 0.2 & 0 & 0.8 & 13.8 \\
\hline Colony count before & 0 & 0 & 0 & 1 \\
\hline therapy (day 30) & 0 & 0 & 0 & 3 \\
\hline \multirow[t]{4}{*}{$10^{3} \mathrm{CFU}$} & 0 & 0 & 0 & 5 \\
\hline & 0 & 0 & 0 & 6 \\
\hline & 0 & 0 & 0 & 1 \\
\hline & 0 & 0 & 0 & 3.2 \\
\hline
\end{tabular}

Table 2: Results of calculating the average of Salmonella bacteria Thy1 in all four groups

\begin{tabular}{llll}
\hline Sample & $\begin{array}{l}\text { Log of colony } \\
\text { count sapodilla } \\
\mathbf{5 1 0 ~} \mathbf{~ m g / k g ~ B B}\end{array}$ & $\begin{array}{l}\text { Log of colony } \\
\text { count sapodilla } \\
\mathbf{7 5 0 ~} \mathbf{~ m g / k g ~ B B}\end{array}$ & $\begin{array}{l}\text { Log of colony count } \\
\text { levofloxacin 98 mg/kg } \\
\text { BB (positive control) }\end{array}$ \\
\hline Colony count before therapy & 24.6 & 17.2 & 30.4 \\
Colony count before therapy (day 5) & 0.2 & 0 & 0.8 \\
Colony count before therapy (day 30) & 0 & 0 & 0 \\
\hline
\end{tabular}

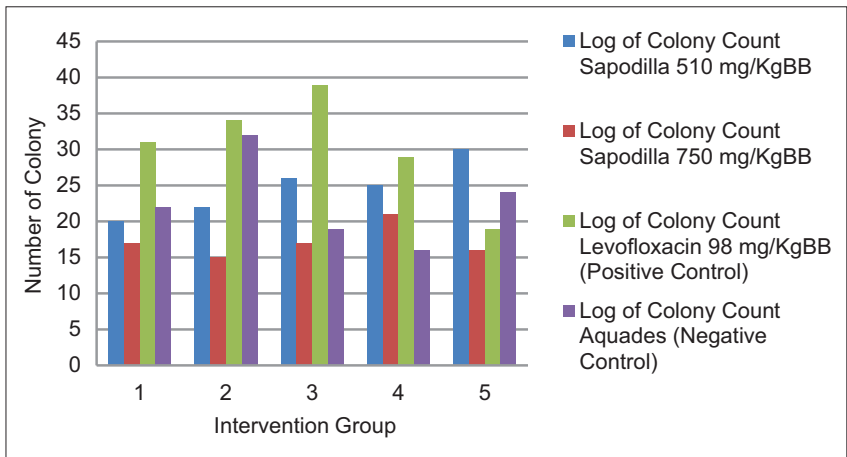

Fig. 1: Results of calculation of Salmonella bacteria Thy1 3 days after induction

extract $510 \mathrm{mg} / \mathrm{kgBB}$, manila extract $750 \mathrm{mg} / \mathrm{kgBB}$, levofloxacin $98 \mathrm{mb} / \mathrm{kgBB}$, and $0.11 \mathrm{cc} / \mathrm{kgBB}$ distilled water showed a significant decrease in bacteria Salmonella Thy1 on day 10 and day 30 after intervention.

Fig. 2 shows the result of calculation of the Salmonella typhi bacterial colonies on day 5 after the intervention of brown manila extract for 4 days found a significant decrease in the number of bacteria. This shows that brown manila extract has the ability to inhibit the growth of Salmonella bacteria from Thy1 as well as the ability of levofloxacin antibiotics in cases of acute infection.

Fig. 3 shows the results of calculating the Salmonella bacteria Thy 1 on the $30^{\text {th }}$ day after intervention. Where we can see a decrease in the number of bacteria to zero in the intervention of brown manila extract $510 \mathrm{mg} / \mathrm{kg}$, extract of $750 \mathrm{mg} / \mathrm{kgBB}$, and levofloxacin manila extract $98 \mathrm{mb} / \mathrm{kgBB}$, whereas for $0.1 \mathrm{cc} / \mathrm{kgBB}$ distilled water, there are still bacteria even though the number decreases. This shows that brown manila extract has the ability to inhibit the growth of Salmonella

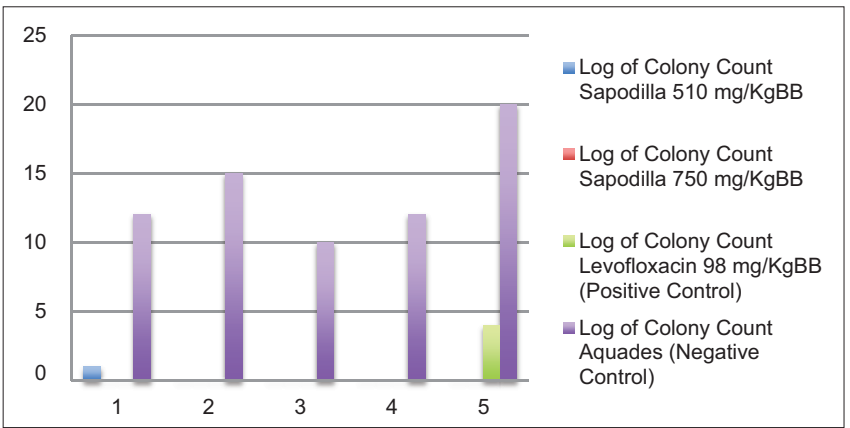

Fig. 2: Results of calculation of Salmonella bacteria Thy1 on day 5 after the intervention of Salmonella bacteria from Thy1

bacteria from Thy 1 as well as the ability of levofloxacin antibiotics in cases of chronic infection.

Fig. 4 shows the results of the calculation of the average Salmonella bacterial colonies on Thy 1 in the four groups of manila extract 510 $\mathrm{mg} / \mathrm{kgBB}$, manila brown extract $750 \mathrm{mg} / \mathrm{kgBB}$, and levofloxacin 98 $\mathrm{mb} / \mathrm{kgBB}$ and distilled water $0.11 \mathrm{cc} / \mathrm{kgBB}$ that there was a significant decrease in Salmonella bacteria in Thy1 on the $10^{\text {th }}$ day and $30^{\text {th }}$ day after intervention; this means that brown manila fruit extract has the ability to inhibit Salmonella bacteria from Thy1 in cases of acute infection and chronic infection similar to the ability of levofloxacin antibiotics, while for aquades group is still obtained bacteria even though the amount decreases.

Table 3 shows the results of the statistical analysis test from the Friedman test and repeated ANOVA test from the four groups. Friedman and repeated ANOVA tests were used to see whether there was a significant decrease in the number of Salmonella bacterial colonies from Thy1 from the four intervention groups on repeated observations of more than two observations (day 5, day 10, and day 30) where the 
Friedman test was used for abnormal data distribution and repeated ANOVA test used for normal data distribution. The results obtained were a significant decrease in manila extract of $510 \mathrm{mg} / \mathrm{kgBB}$ with a value of $p=0.009(p<0.05)$, a significant decrease in the administration of manila extract $750 \mathrm{mg} / \mathrm{kgBB}$ with a value of $\mathrm{p}=0.007(\mathrm{p}<0.05)$, a significant decrease in the administration of levofloxacin $98 \mathrm{mg} / \mathrm{kgBB}$ with a value of $p=0.009(p<0.05)$, and a significant decrease in the administration of $0.11 \mathrm{cc} / \mathrm{kgBB}$ distilled water with a value of $\mathrm{p}=0.004(\mathrm{p}<0.05)$.

Table 4 shows the results of the statistical analysis test from the Wilcoxon test and paired t-test from the four groups. Wilcoxon and

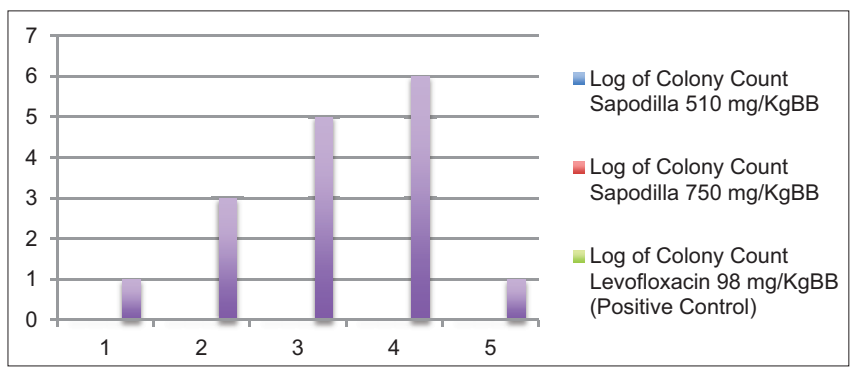

Fig. 3: Results of calculation of Salmonella bacterial colonies from Thy 1 on day 30 after the intervention

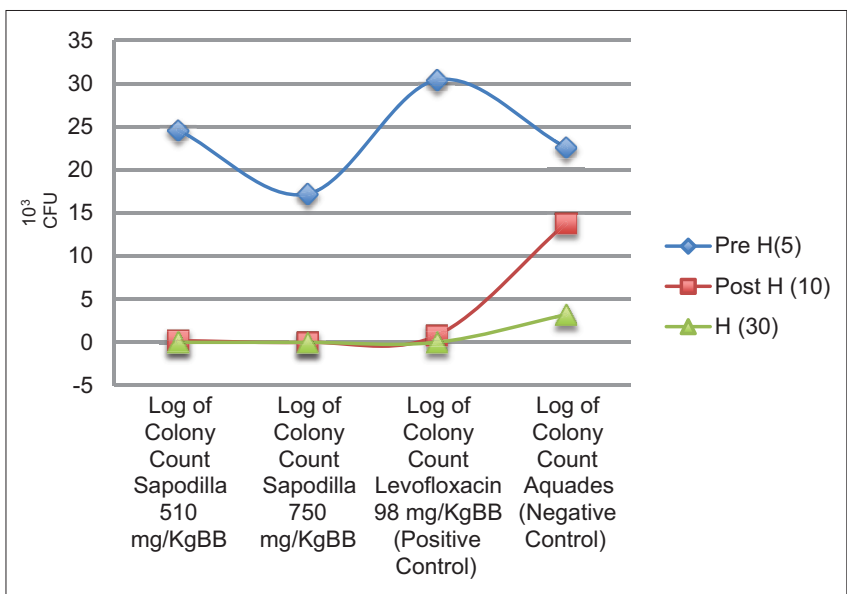

Fig. 4: Results of calculation of the average colonies of Salmonella bacteria from Thy1 in all four groups t-paired tests were used to see whether there was a significant decrease in the number of Salmonella bacteria colonies in Thy 1 on two repeated observations, namely, day 5 and day 10, day 10 and day 30 , and day 5 and day 30 from the four intervention groups. The Wilcoxon test is used for abnormal data distribution and the paired t-test is used for normal data distribution. The results obtained were: For observation of the $5^{\text {th }}$ and $10^{\text {th }}$ days there was a significant decrease in manila extract of $510 \mathrm{mg} / \mathrm{kgBB}$ with a value of $\mathrm{p}=0.043$ $(\mathrm{p}<0.05)$, a significant decrease in administration of $750 \mathrm{mg}$ manila sapodilla extract $/ \mathrm{kgBB}$ with a value of $\mathrm{p}=0.042(\mathrm{p}<0.05)$, a significant decrease in the administration of levofloxacin $98 \mathrm{mg} / \mathrm{kgBB}$ with a value of $\mathrm{p}=0.043(\mathrm{p}<0.05)$, and a significant decrease in the administration of $0.11 \mathrm{cc} / \mathrm{kgBB}$ distilled water with a value of $p=0.021(p<0.05)$. For observation of the $10^{\text {th }}$ day and $30^{\text {th }}$ day, there was no significant decrease in manila extract of $510 \mathrm{mg} / \mathrm{kgBW}$ with a value of $p=0.317$ ( $p>0.05)$, there was no significant decrease in extract of manila extract $750 \mathrm{mg} / \mathrm{kgBB}$ with a value of $\mathrm{p}=1.000$ ( $p>0.05)$, there was no significant decrease in the administration of levofloxacin $98 \mathrm{mg} / \mathrm{kgBB}$ with a value of $\mathrm{p}=0.317$ ( $\mathrm{p}>0.05)$, and a significant decrease in the administration of $0.11 \mathrm{cc} /$ aquades $\mathrm{kgBB}$ with a value of $\mathrm{p}=0.013(\mathrm{p}<0.05)$. For observations on day 5 and day 30 , there was a significant decrease in the administration of manila extract $510 \mathrm{mg} / \mathrm{kg}$ with a value of $\mathrm{p}=0.043(\mathrm{p}<0.05)$, a significant decrease in the administration of manila extract $750 \mathrm{mg} / \mathrm{kgBW}$ with $\mathrm{p}=0.042(\mathrm{p}<0.05)$, a significant decrease in levofloxacin $98 \mathrm{mg} / \mathrm{kgBW}$ with $\mathrm{p}=0.043(\mathrm{p}<0.05)$, and a significant decrease in $0.11 \mathrm{cc} / \mathrm{kgBB}$ aquades with $\mathrm{p}=0.004(\mathrm{p}<0.05)$.

Table 5 shows the results of the statistical analysis test from the ANOVA test and the Kruskal-Wallis test from the four groups. ANOVA and Kruskal-Wallis tests were used to see whether or not there was a difference from the decrease in the number of Salmonella bacterial colonies from Thy 1 from the four intervention groups on observation (day 5, day 10, and day 30) where the Kruskal-Wallis test was used for abnormal data distribution, and ANOVA test is used for normal data distribution. The results obtained are the existence of a significant difference in the decline on the $5^{\text {th }}$ day of observation with a value of $p=0.000(p<0.05)$, on the observation of the $10^{\text {th }}$ day, there was no significant difference in the value of $p=0.581(\mathrm{p}<0.05)$ in observation of the $30^{\text {th }}$ day there was a significant decrease in the value of $p=0.010$ $(\mathrm{p}<0.05)$.

S. typhi Thy1 bacteria enter the body through the digestive tract, then go to the ileum and then penetrate the blood vessels to spread systemically through circulation [17]. Most bacteria will die by gastric acid and a large number of bacteria that have good defenses will

Table 3: The results of the statistical analysis test from the Friedman test and repeated ANOVA test from the four groups

\begin{tabular}{llll}
\hline Group & Day $\mathbf{5}$ & Day $\mathbf{1 0}$ & p \\
\hline Sapodilla $510 \mathrm{mg} / \mathrm{kg} \mathrm{BB}$, mean \pm SD & $24.60 \pm 3.85$ & $0.20 \pm 0.45$ & $0.00 \pm 0.00$ \\
Sapodilla $750 \mathrm{mg} / \mathrm{kg} \mathrm{BB}$, mean \pm SD & $17.20 \pm 2.28$ & $0.00 \pm 0.00$ & $0.00 \pm 0.00$ \\
Levofloxacin $98 \mathrm{mg} / \mathrm{kg} \mathrm{BB}$, mean \pm SD & $30.40 \pm 7.40$ & $0.80 \pm 1.79$ & $0.007 *$ \\
Aquadest, mean \pm SD & $22.60 \pm 6.07$ & $13.80 \pm 3.90$ & $0.009 *$ \\
\hline
\end{tabular}

*Friedman test, ${ }^{* *}$ repeated ANOVA test. SD: Standard deviation

Table 4: Shows the results of the statistical analysis test from the Wilcoxon test and paired t-test from the four groups

\begin{tabular}{|c|c|c|c|c|c|c|c|c|c|}
\hline Group & Day 5 & Day 10 & $\mathbf{p}$ & Day 10 & Day 30 & $\mathbf{p}$ & Day 5 & Day 30 & $\mathbf{p}$ \\
\hline $\begin{array}{l}\text { Sapodilla } 510 \text { mg/kg BB, } \\
\text { mean } \pm \text { SD }\end{array}$ & $24.60 \pm 3.85$ & $0.20 \pm 0.45$ & $0.043^{*}$ & $0.20 \pm 0.45$ & $0.00 \pm 0.00$ & $0.317^{*}$ & $24.60 \pm 3.85$ & $0.00 \pm 0.00$ & $0.043^{*}$ \\
\hline $\begin{array}{l}\text { Sapodilla } 750 \text { mg } / \mathrm{kg} \mathrm{BB} \text {, } \\
\text { mean } \pm S D\end{array}$ & $17.20 \pm 2.28$ & $0.00 \pm 0.00$ & $0.042^{*}$ & $0.00 \pm 0.00$ & $0.00 \pm 0.00$ & $1.000^{*}$ & $17.20 \pm 2.28$ & $0.00 \pm 0.00$ & $0.042^{*}$ \\
\hline $\begin{array}{l}\text { Levofloxacin } 98 \mathrm{mg} / \mathrm{kg} \\
\mathrm{BB}, \text { mean } \pm \mathrm{SD}\end{array}$ & $30.40 \pm 7.40$ & $0.80 \pm 1.79$ & $0.043^{*}$ & $0.80 \pm 1.79$ & $0.00 \pm 0.00$ & $0.317^{*}$ & $30.40 \pm 7.40$ & $0.00 \pm 0.00$ & $0.043^{*}$ \\
\hline Aquadest, mean $\pm S D$ & $22.60 \pm 6.07$ & $13.80 \pm 3.90$ & $0.021^{* *}$ & $13.80 \pm 3.90$ & $3.20 \pm 2.28$ & $0.013^{* *}$ & $22.60 \pm 6.07$ & $3.20 \pm 2.28$ & $0.004^{* *}$ \\
\hline
\end{tabular}

*Wilcoxon test, ${ }^{* *}$ t paired test. SD: Standard deviation 
Table 5: Test results for statistical analysis of the ANOVA test and Kruskal-Wallis test from the four groups

\begin{tabular}{llll}
\hline Group & Day 5 & Day 10 & Day 30 \\
\hline $\begin{array}{l}\text { Sapodilla } 510 \mathrm{mg} / \mathrm{kg} \\
\text { BB, mean } \pm \text { SD }\end{array}$ & $-24.40 \pm 4.16$ & $-0.20 \pm 0.45$ & $-24.60 \pm 3.85$ \\
$\begin{array}{l}\text { Sapodilla 750 mg/kg } \\
\text { BB, mean } \pm \text { SD }\end{array}$ & $-17.20 \pm 2.28$ & $0.00 \pm 0.00$ & $-17.20 \pm 2.28$ \\
Levofloxacin 98 mg/kg & $-29.60 \pm 8.99$ & $-0.80 \pm 1.79$ & $-30.40 \pm 7.40$ \\
BB, mean \pm SD & & & \\
Aquadest, mean $\pm S D$ & $-8.80 \pm 5.36$ & $-10.60 \pm 5.59$ & $-19.40 \pm 7.50$ \\
Nilai p & $0.000^{*}$ & $0.581^{* *}$ & $0.010^{*}$ \\
\hline
\end{tabular}

*ANOVA test, ${ }^{* *}$ Kruskal-Wallis test. SD: Standard deviation

reach the intestine and can provide clinical manifestations of typhoid fever [18]

Sapodilla manila is known to have an antimicrobial effect after testing using ethyl acetate extract from raw brown manila fruit and found antimicrobial activity against several bacteria such as Bacillus subtilis, Escherichia coli, and $S$. typhi with inhibitory zones of about 8-16 mm [19]. In addition, brown manila fruit extract also has an antiinflammatory effect after conducting in vitro and in vivo studies using ethyl acetate extracts obtained significant anti-inflammatory activity on methanol extract because of the presence of flavonoids, tannins, and terpenoids [20]. Research conducted by Amlan Ganguly in 2013 entitled anti-inflammatory and antipyretic activity in vivo on Manilkara zapota in albino Wistar rats found that ethanol extract in sapodilla manila fruit at $300 \mathrm{mg} / \mathrm{kg}$ can inhibit inflammation in swollen rat thighs significantly [21].

This study has proven that manila extract has the ability to inhibit the growth of Salmonella bacteria Thy1 in vivo. The results were obtained after the treatment of sapodilla manila $510 \mathrm{mg} / \mathrm{kgBB}$ extract and sapodilla manila $750 \mathrm{mg} / \mathrm{kgBB}$ extract for 5 days showed a significant decrease in the number of colonies in intraperitoneal fluid from mice infected with Salmonella bacteria in Thy1, the same effect was obtained in positive control, namely, levofloxacin $98 \mathrm{mb} / \mathrm{kgBB}$ so we can conclude that brown manila extract has an antimicrobial effect on Salmonella bacteria thypi1.

This is in line with other studies which prove that manila sapodilla has the ability to increase the growth of pathogenic bacteria that cause in the human intestine by preventing further inflammation and more dangerous effects [22]. In addition, studies carried out using spectroscopic measurements showed that brown manila fruit also has compounds that can suppress the growth activity of typhoid fever-causing bacteria [23]. Typhoid fever may present as sustained fever, headache, abdominal pain, nausea, loss of appetite, and constipation or sometimes diarrhea. However, typhoid fever may be difficult to confirm if the diagnosis is based only on the clinical presentation [24].

\section{CONCLUSION}

Sawo Manila has long been used empirically by the Indonesian people as traditional medicine for typhoid fever. In this study, we found that administration of manila extract $510 \mathrm{mg} / \mathrm{kgBB}$ and $750 \mathrm{mg} / \mathrm{kgBB}$ had the same effect in suppressing the growth of Salmonella bacteria thypi1. Therefore, it is recommended to use smaller doses of $510 \mathrm{mg} / \mathrm{kg}$. We conclude that administration of manila $510 \mathrm{mg} / \mathrm{kgBB}$ extract can be considered as a substitute for treating typhoid fever, thereby reducing the occurrence of antibiotic resistance in the community.

\section{ACKNOWLEDGMENT}

I am very grateful to all those who have helped in the implementation of this research, especially my supervisor, laboratory staff, and my friends who always support me. As well as to the management of the Indonesian Education Fund (LPDP) which has provided the full contribution of this research fund.

\section{COFLICTS OF INTEREST}

There are no conflicts of interest within this review article and publication.

\section{REFERENCES}

1. García M. Typhoid Fever in Nineteenth-Century Colombia : Between Medical Geography and Bacteriology. Vol. 58. Cambridge: Cambridge University Press; 2014. p. 27-45.

2. Wijedoru L, Mallett S, Parry CM. Rapid diagnostic tests for typhoid and paratyphoid (enteric) fever. Cochrane Database Syst Rev 2017;5:CD008892.

3. Handerson A. Typhoid fever. Emerg Acute Infect Dis Guidel 2017;4:359-67.

4. Li Z, Zheng Q, Xue XY, Shi X. Pyroptosis of Salmonella typhimurium infected macrophages was suppressed and elimination of intracellular bacteria from macrophages was promoted by blocking QseC. Sci Rep 2016;37:1-12

5. Vinod N, Noh HB, Oh S, Ji S, Park HJ, Lee KS, et al. A Salmonella typhimurium ghost vaccine induces cytokine expression in vitro and immune responses in vivo and protects rats against homologous and heterologous challenges. PLoS One 2017;12:e0185488.

6. Ramachandran G, Panda A, Higginson EE, Ateh E, Detolla J, Tennant SM. Virulence of invasive Salmonella typhimurium ST313 in animal models of infection. Negl Trop Dis 2017;23:1-14.

7. Kiyuna T, Murakami T, Tome Y, Kawaguchi K, Igarashi K, Zhang Y, et al. High efficacy of tumor-targeting Salmonella typhimurium A1-R on a doxorubicin- and dactolisib-resistant follicular dendritic-cell sarcoma in a patient-derived orthotopic xenograft PDOX nude mouse model. Oncotarget 2016;7:33046-54.

8. Keddy KH, Sooka A, Smith AM, Musekiwa A, Tau NP, Klugman KP, et al. Typhoid fever in South Africa in an endemic HIV setting. J PLoS One 2016;8:1-12.

9. Antillón M, Warren JL, Crawford FW, Weinberger DM, Kürüm E, Pak GD, et al. The burden of typhoid fever in low and middleincome countries: A meta-regression approach. PLoS Negl Trop Dis 2017; 11:e0005376.

10. Srivastava M, Hegde M, Chiruvella KK, Koroth J, Bhattacharya S, Choudhary B, et al. Sapodilla plum (Achras sapota) induces apoptosis in cancer cell lines and inhibits tumor progression in mice. Sci Rep 2014;4:6147.

11. Tan BL, Norhaizan ME, Chan LC. ROS-mediated mitochondrial pathway is required for Manilkara zapota (L.) P. Royen leaf methanol extract inducing apoptosis in the modulation of caspase activation and EGFR/NF- $\kappa$ B activities of heLa human cervical cancer cells. Evid Based Complement Alternat Med 2018;2018:6578648.

12. Devatkal SK, Kumboj R, Paul D. Comparative antioxidant effect of BHT and water extracts of banana and sapodilla peels in raw poultry meat. J Food Sci Technol 2014;51:387-91.

13. Altemimi A, Lakhssassi N, Baharlouei A, Watson DG, Lightfoot DA. Phytochemicals: Extraction, isolation, and identification of bioactive compounds from plant extracts. Plants (Basel) 2017;6:E42.

14. Gupta A, Kothari V. Modern extraction methods for preparation of bioactive plant extracts. Int J Appl Nat Sci 2014;1:9-18.

15. Bandar H, Hijazi A, Rammal H, Hachem A, Saad Z. Techniques for the extraction of bioactive compounds from lebanese urtica dioica. Am J Phytomed Clin Ther 2016;1:2-7.

16. Yeo YL, Chia YY, Lee CH, Sow HS, Yap WS. Effectiveness of maceration periods with different extraction solvents on in vitro antimicrobial activity from fruit of momordica. J Appl Pharm Sci 2014; $4: 16-23$

17. Shungu DL, Cook TM. Induction of P22 prophage in Salmonella typhimurium by hycanthone. J Virol 2013;13:1153-4.

18. Thanh DP, Thompson CN, Rabaa MA, Sona S, Sopheary S, Kumar V, et al. The molecular and spatial epidemiology of typhoid fever in rural cambodia. Negl Trop Dis 20165:1-16.

19. Moo-huchin VM, Estrada I. Responses of sapodilla fruit (Manilkara zapota [L.] P. Royen) to postharvest treatment with 1-methylcyclopropene. Afr J Agric Res 2013;8:2.

20. Lim WS, Rabea MS, Uthumporn U. Development of functional beverage from sapodilla (Manilkara Zapota L) fruit. Food Res 2018;2:163-70. 
21. Morais PL, Miranda MR, Lima LC, Alves JD, Alves RE, Silva JD. Cell wall biochemistry of sapodilla (Manilkara zapota) submitted to 1-methylcyclopropene. Braz J Plant Physiol 2015;20:85-94.

22. Qiuping Z, Wenshui X, Jiang Y. Effects of 1-methylcyclopropene treatments on ripening and quality of harvested sapodilla fruit. Food Technol Biotech 2006;44:535-9.

23. Mogasale V, Mogasale VV, Ramani E, Lee JS, Park JY, Lee KS, et al. Revisiting typhoid fever surveillance in low and middle income countries: Lessons from systematic literature review of populationbased longitudinal studies. BMC Infect Dis 2016;16:35.

24. Kaljee LM, Pach A, Thriemer K, Ley B, Ali SM, Jiddawi M, et al. Utilization and accessibility of healthcare on pemba island, Tanzania: Implications for health outcomes and disease surveillance for typhoid fever. Am J Trop Med Hyg 2013;88:144-52. 